\title{
PERANAN BIMBINGAN DAN KONSELING ISLAMI DALAM MENANGGULANGI KEHAMILAN DI LUAR NIKAH
}

\author{
Ibnu Mahmudi
}

\begin{abstract}
Abstrak
Bimbingan dan Konseling secara yuridis diakui keberadaannya di Indoensia pada kurikulum 1975. Dalam pelaksanaannya belum bisa maksimal karena masih banyak masalah yang belum bisa diantisipasi atau dicegah khususnya terjadinya kehamilan di luar nikah.

Hasil penelitian menunjukkan kehamilan di luar nikah semakin meningkat. Kenyataan semacam ini masih belum dilakukan pencegahan oleh bimbingan dan konseling sekolah sehingga diperlukan upaya pencegahan. Dari berbagai hasil penelitian menyimpulkan bahwa di antara penyebab tersebut adalah kurang adanya pengawasan dari orang tua, kurang mengamalkan ajaran agama dengan baik dan benar
\end{abstract}

Kata Kunci: bimbingan dan konseling Islami, mencegah kehamilan di luar nikah

\section{Pendahuluan}

Bimbingan dan konseling di sekolah secara formal diakui keberadaanya sejak kurikulum 1975. Dalam perkembangannya bimbingan dan konseling punya peran penting dalam upaya pencegahan terjadinya masalah pada individu. Masalah yang biasanya dihadapi siswa di sekolah adalah berkaitan dengan masalah pribadi, sosial, belajar dan karir. Sekolah sebagai lembaga pendidikan formal mempunyai tanggung jawab penting dalam usaha membantu individu agar dapat menyelesaikan masalahnya sendiri. Namun hasilnya belum mengembirakan, masih banyak individu yang belum bisa berkembang secara optimal .

Akhir tahun 2010 muncul berita diberbagai media cetak dan elektronik ada beberapa siswi sekolah mengalami kehamilan di luar nikah . Melihat kejadian seperti sekolah tampak kurang siap untuk mengantisipasi kenyataan tersebut. 
Konselor sekolah selaku petugas bimbingan dan konseling di sekolah, nampaknya belum maksimal dalam mencegah terjadinya masalah pada siswinya. Untuk menangani masalah tersebut perlu di cari metode yang tepat untuk menyelesaikannya antara lain melalui bimbingan dan konseling Islami.

Bimbingan dan konseling Islami sebagai salah satu model dalam bimbingan dan konseling dharapkan dapat dijadikan sebagai salah satu cara tepat dalam upaya mencegah terjadinya kehamilan di luar nikah, karena bimbingan dan konseling Islami hakekatnya adalah upaya untuk membantu individu agar tidak tertimpa masalah melalui konsep yang berdasar pada Al-Qur'an dan Al-Hadits.

Tantri Yusepa (2010) melakukan penelitian tentang "Pengaruh Perhatian Orangtua dan Frekuensi Mengikuti Kegiatan Agama Terhadap Kecenderungan Melakukan Hubungan Seks Saat Berpacaran", menunjukan hasil yang signifikan dengan r-hitung sebesar $0,740>$ r-tabel 0,426 dengan 3 variabel dan $\mathrm{db} 30$. Artinya "Ada pengaruh perhatian orangtua dan frekuensi mengikuti kegiatan agama terhadap kecenderungan melakukan hubungan seks saat berpacaran.” Artinya anak yang aktif mengikuti kegiatan keagamaan ada kecedenrungan untuk tidak melakukan hubungan seks sebelum nikah.

\section{Pembahasan}

1. Bimbingan dan Konseling Islami

Hakikat Konseling Islami adalah upaya membantu individu pelajar mengembangkan fitrah iman dan atau kembali kepada fitrah-iman, dengan cara memberdayakan fitrah-fitrah (jasmani, nafs, dan iman) mempelajari dan melaksanakan tuntunan Allah dan Rasul-Nya, agarafitrah-fitrh yang ada pada individu berkembang dan berfungsi dengan baik dan benar. Pada akhirnya 
diharapkan agar individu selamat dan memperoleh kebahagiaan yang sejati di dunia dan akhirat

Tohari (dalam Muslimatun, 2009) menyatakan bahwa bimbingan dan konseling Islami merupakan aspek program pendidikan yang berperan pada bantuan terhadap para siswa agar dapat menyesuaikan diri dengan situasi yang dihadapinya untuk merencanakan masa depan sesuai dengan minat, kemampuan dan keadaan sosialnya, atau bantuan kepada siswa agar dapat mengenal dirinya sehingga dapat mencapai hidup bahagia (dalam konteks kebahagiaan dunia akhirat)

Menurut Yahya Jaya (2004: 108), bimbingan dan konseling Islami adalah layanan bantuan yang diberikan konseling agama kepada manusia yang mengalami masalah dalam hidup keberagaman, ingin mengembangkan dimensi dan potensi keberagamannya seoptimal mungkin secara individu maupun kelompok, agar menjadi manusia mandiri dan dewasa dalam beragama, berdasarkan pada keimanan dan taqwa yang terdapat dalam AlQur'an dan Hadist.

Choliq Dahlan (dalam Muslimatun, 2009) menjelaskan bahwa bimbingan dan konseling Islami didasarkan pada ajaran Islam yang berada dalam Al-Qur'an dan As-sunnah dengan landasan kerja pemberian layanan:

a. Sebagaimana yang disampaikann Abdul Cholik bimbingan dan konseling Islami mengikuti bimbingan dan konseling konvensional yang dilaksanakan secara Islam.

b. Memberikan bimbingan dan konseling yang sepenuhnya bersumber dari ajaran Islam yaitu Al-Qur'an dan As-sunnah. 
c. Kegiatan bimbingan dan konseling Islami dilandasi adanya pemikiran bahwa aktivitas siswa didasarkan pada orientasi tauhid, yaitu motivasi beribadah.

d. Internalisasi ajaran Islam oleh siswa dapat berjalan melalui proses bimbingan dan konseling Islami

e. Kegiatan bimbingan dan konseling Islami telah terprogram dan berstruktur.

f. Mengubah perilaku dan lingkungan melalui conditioning dan modeling.

Tujuan bimbingan dan konseling islami adalah agar fitrah yang dikaruniakan Allah kepada individu bisa berkembang dan berfungsi dengan baik, sehingga menjadi pribadi kaaffah, dan secara betahap mampu mengaktualisasikan apa yang diimaninya itu dalam kehidupan sehari-hari, yang tampil dalam bentuk kepatuhan terhadap hukum-hukum Allah dalam melaksanakan tugas kekhalifahan di bumi, dan ketaatan dalam beribadah dengan segala perintah-Nya dan menjauhi segala larangan-Nya. Dengan kata lain, tujuan konseling model ini adalah meningkatkan Iman, Islam, dan Ikhsan individu yang dibimbing hingga muncul pribadi yang utuh. Dan pada akhirnya diharapkan mereka bisa hidup bahagia di dunia dan akhirat.

2. Tujuan Konseling Islami

M Hamdani Bakran Adz-Dazky (2002) menjelaskan tujuan konseling dalam Islam sebagai berikut.

a. Untuk menghasilkan suatu perubahan, perbaikan, kesehatan dan kebersihan jiwa dan mental. Jiwa menjadi tenang, jinak dan damai 
(muthmainnah), bersikap lapang dada (radhiyah) dan mendapatkan pencerahan taufik dan hidayah Tuhannya (mardhiyah)

b. Untuk menghasilkan suatu perubahan, perbaikan dan kesopanan tingkah lakuyang dapat memberikan manfaat baik pada diri sendiri,lingkungan keluarga, lingkungan kerja maupun lingkungan sosial dan alam sekitarnya.

c. Untuk menghasilkan kecerdasar rasa (emosi) pada individu sehingga muncul dan berkembang pada individu sehingga muncul dan berkembang rasa toleransi, kesetiakawanan, tolong menolong dan rasa kasih sayang.

d. Untuk menghasilkan kecerdasan spiritual pada diri individu sehingga muncul dan berkembang rasa keinginan untuk berbuat taat kepada Tuannya spiritual pada diri individu sehingga muncul dan berkembang rasa keinginan untuk berbuat taat kepada Tuhannya, ketulusan mematuhi segala peerintah-Nya serta ketabahan menerima ujian-Nya.

e. Untuk menghasilkkan potensi Ilahiyah, sehingga dengan potensi itu individu dapat melakukan tugasnya sebagai khalifah dengan baik dan benar, ia dapat dengan baik menanggulangi berbagai persoalan hidup dan dapat memberikan kemanfaatan dan keselamatan bagi lingkungannya dan keselamatan pada berbagai aspek kehidupan.

3. Beberapa Teori Konseling dalam Islam

M Hamdani Bakran Adz-Dazky (2002) menjelaskan sebagai berikut.

a. Teori "Al-Hikmah"

Kata "Al-Hikmah" dalam perspekti bahasa mengandung makna (a) mengetahui keunggulan sesuatu melalui suatu pengetahuan, sempurna, 
bijaksana dan suatu yang tergantung padanya akibat sesuatu yang terpuji.' (b) ucapan yang sesuai dengan kebenaran, filsafat, perkara yang benar dan lurus, keadilan, pengetahuan dan lapang dada." (c) kata Al-Hikmah" dengan bentuk jamaknya "Al-Hikam" bermakna kebijaksanaan, ilmu dengan pengetahuan, filsafat, kenabian, keadilan, pepatah dan "Al-Qur'an Al-Karim”

Teori Al-Hikmah adalah sebuah pedoman, penuntun dan pembimbing, untuk memberi bantuan kepada individu yang sangat membutuhkan pertolongan dalam mendidik dan mengembangkan eksistensi dirinya hingga dapat menemukan jati diri dan citranya serta dapat menyelesaikan atau mengatasi berbagai ujian hidup secara mandiri. Proses aplikasi konselng dengan teori ini semata-mata dapat dilaksanakan konselor dengan pertolongan Allah secara langsung atau melalui utusanNya, yaitu Allah mengutus Malaikat-Nya, dimana ia hadir dalam jiwa konselor atas izin-Nya.

Teori ini tidak dapat dilakukan oleh konselor yang tidak taat, tidak dekat dengan Allah dan Malaikat-Nya, karena teori ini merupakan teori konseling yang dilakukan para Rasul, Nabi dan Aulia Allah serta menyangkut problem dan penyakit yang paling berat dan tidak dapat disembuhkan dengan cara-cara manusia atau makhluk., seperti penyimpangan perilaku yang diakibatkan kaerena terganggunya jiwa dan yang menyebabkan jiwa terganggu itu adalah akibat ulah syetan dan iblis, dimana mereka bersenyawa dalam jiwa dan menggerakkan seluruh 
aktifitas individu dalam perilaku yang dapat membahayakan dirinya sendiri maupun lingkungannya.

Ciri khas dari teori konseling dengan Al-Hikmah ialah berupa:

1) Adanya pertolongan Allah SWT, secara langsung atau melalui malaikat-Nya;

2) Diagnosis menggunakan metode ilham (intuisi) dan kasysyaf. (penyingkapan batin);

3) Adanya keteladanan dan keshalihan konselor;

4) Alat terapi yang dilakukan adalah nasehat-nasehat dengan menggunakan teknik Ilahiyah, yaitu dengan do'a, ayat-ayat Al-Qur'an dan menerangkan esensi dari problem yang sedang dialami;

5) Teori Al-Hikmah ini biasanya khusus dilakukan untuk terapi penyakit yang berat dan konseli tidak dapat melakukannya sendiri, tetapi merlalui bantuan terapis, seperti penyimpangan perilaku karena adanya interfensi syetan atau iblis dalam kejiwaan seseorang.

b. Teori "Al-Mauizhoh Al-Hasanah"

Yaitu bimbingan dan konseling dengan cara mengambil pelajaran dari perjalanan kehidupan para Nabi, Rasul dan para Aulia Allah. Dalam penggunaan teori ini sebelumnya konselor harus benar-benar telah menguasai dengan baik sejarah, riwayat hidup dan perjuangan orangorang agung, pejabat-pejabat Allah dan kekasih-Nya, khususnya Rasulullah SAW.

Materi Al-Mau'izhoh Al-Hasanah dapat diambil dari sumbersumber pokok ajaran Islam maupun dari para pakar selama tidak 
bertentangan dengan norma-norma Islam tersebut. Sumber-sumber yang dimaksud itu adalah

1) Al-Qur'an Al-Karim

2) As-Sunnah (Perilaku Rasulullah SAW)

3) $\mathrm{Al}$-Atsar (perilaku para sahabat Nabi)

4) Pendapat atau ijtihad para Ulama Muslim.

5) Pendapat atau penemuan-penemuan para pakar non Muslim seperti terapi psikoanalitik Freud; terapi eksistensial-humanistik dari May. Maslow, Frangke dan Jourarat; terapi client-centered dari Calr Rogers; terapi Gestalt dan lain-lain.

c. Teori Mujadalah bil Ikhsan

Teori mujadalah adalah teori konseling yang terjadi dimana seorang konseli sedang dalam kebimbangan. Teori ini biasa digunakan ketika seorang konseli ingin mencari suatu kebenaran yang dapat menyakinkan dirinya, yang selama ini ia memiliki problem kesulitan mengambil suatu keputusan dari dua hal atau lebih, sedangkan ia berasumsi bahwa kedua atau lebih itu baik dan benar untuk dirinya. Pada hal dalam pandangan konselor itu dapat membahayakan perkembangan jiwanya, akal fikirannya, emosionalnya dan lingkunganya.

Permasalahan yang dialami seorang konseli seperti ini sangat sering dijumpai dalam kehidupan sehari-hari. Ketika ada seorang ibu muda sedang memiliki problem dalam keluarganya.

Prinsip-prinsip teori ini adalah: 
1) Harus adanya kesabaran yang tinggi dari konselor

2) Konselor harus menguasai akar permasalahan dan terapinya dengan baik.

3) Saling menghormati dan menghargai.

4) Bukan bertujuan menjatuhkan atau mengalahkan konseli, tetapi membimbing konseli dalam mencari kebenaran.

5) Rasa persaudaran dan penuh kasih sayang.

6) Tutur kata dan bahasa yang mudah dipahami dan halus.

7) Tidak menyinggung perasaan konseli.

8) Mengemukakan dalil-dalil Al-Qur'an dan As-Sunnah dengan tepat dan jelas.

9) Keteladanan yang sejati. Artinya apa yang konselor lakukan dalam proses konseling benar-benar telah dipahami, diaplikasikan dan dialami konselor, karena Allah sangat murka kepada orang yang tidak mengamalkan apa yang ia nasehatkan kepada orang lain.

Dari penjelasan tentang teori konseling dalam Islam diatas maka dapat disimpulkan bahwa:

1) Teori konseling pendekatan Al-Hikmah ialah melihat esensi permasalahan yang terjadi atau terdapat dalam diri individu, kemudian menjelaskan tentang hikmah, rahasia atau pengetahuan yang terdapat dibalik permasalahan itu. Setelah itu baru konselor melakukan bimbingan dan konseling dengan kekuatan yang dianugerahkan Allah SWT kedalam dirinya berupa energi penyembuh. Energi itu terekspresi pada pandangan mata, ucapan atau tindakannya. 
2) Teori konseling "Al-Mauizhoh Al-Hasanah" lebih melihat model atau kasus yang dihadapi individu, kemudian proses terapinya atau penanggulangannya mencontoh atau berparadigma kepada proses kenabian. Bagaimana para Nabi, Rasul dan para Auliya Allah melakukan peerbaikan, melakukan perubahan dalam masalah kepribadian sehingga mereka menjadi insan kamil yaitu manusia yang memiliki potensi Ilahiyah yang sempurna, tidak hanya di bumi tetapi juga di langit, tidak hanya dunia tetapi juga di akhirat dan tidak haya dihadapan Tuhannya tetapi juga dihadapan makhluk-Nya.

3) Teori konseling Al-Mujadalah bil Ikhsan menitikbeeratkaan kepad individu yang membutuhkan kekuatan dalam keyakinan dan ingin menghilangkan keraguan, was-was dan prasangka-prasangka negatif terhadap kebenaran Ilahiyah yang selalu bergema dalam nuraninya,

\section{Tahap-tahap Bimbingan dan Konseling Islami}

Anwar Sutoyo (2007) mengemukakan tahap-tahap bimbingan dan konseling islami sebagai berikut:

a. Meyakinkan individu tentang hal-hal sesuai dengan kebutuhannya antara lain:

1) Posisi manusia sebagai makhluk ciptaan Allah, bahwa ada hukumhukum atau ketentuan Allah (sunnatullah) yang berlaku bagi setiap manusia.

2) Status manusia sebagai hamba Allah yang harus selalu tunduk dan patuh kepada-Nya. Ada perintah dan larangan Allah yang harus dipatuhi oleh semua manusia sepanjang hidpnya, dan pada saatnya 
akan dimintai tanggung jawab oleh Allah tentang apa yang pernah dilakukan selama hidup di dunia.

3) Tujuan Allah menciptakan manusia adalah agar manusia melaksanakan amanah dalam bidang keahlian masing-masing sesuai ketentuan Allah dan sekaligus beribadah kepada-Nya.

4) Ada fitrah yang dikaruniakan Allah kepada manusia, bahwa manusia sejak lahir dilengkapi dengan fitrah berupa iman dan taat kepada-Nya. Tugas manusia adalah memelihara, mengembangkan, dan ketika menjauh segera kembali kepada fitrah-nya.

5) Iman yang benar sangat penting bagi keselamatan hidpnya di dunia dan akhirat. Tugas manusia adalah memelihara dan menyuburkannya dengan selalu mempelajari dan mentaati tuntunan agama.

6) Iman bukan hanya pengakuan dengan mulut, tetapi lebih dari itu adalah membenarkan dengan hati dan mewujudkan apa yang diimaninya itu dalam kehidupan sehari-hari

7) Ada hikmah di balik masibah, ibadah dan syari'ah yang ditetapkan Allah untuk manusia. Kewajiban manusia adalah menerima dengan ikhlas apa yang ditetapkan Allah untuknya dan melaksanakan sesuai syariat-Nya.

8) Ada suatu keharusan menanamkan aqidah yang benar pada anak sejak usia dini, menjauhkan dari syirik, dan membiasakan setiap anggota keluarga melaksanakan ibadah dan beramal saleh secara benar dan istiqomah. 
9) Ada setan yang selalu berupaya menyesatkan manusia dari jalan Allah, agar manusia selamat dari bujuk rayu setan, Allah menganugerahkan potensi berupa akal pikiran, perasaan dan tuntutan agama kepada manusia.

10) Ada hak manusia untuk berikhtiar atau berusaha semaksimal mungkin, tetapi perlu diingat bahwa sebagian dari keberhasilannya masih tergantung pada idzin Allah.

11) Tugas konselor hanyalah membantu, individu sendiri yang harus berupaya sekuat tenaga dan kemampuannya untuk hidup sesuai tuntunan agama.

b. Mendorong dan membantu individu memahami dan mengamalkan ajaran agama secara benar.

Pada tahap ini konselor mengingatkan individu : (a) agar individu selamat hidupnya di dunia dan akhirat, maka harus menjadikan ajaran agama sebagai pedoman dalam setiap langkahnya; dan untuk itu individu harus memahami ajaran agama Islam secara baik dan benar; (b) mengingat ajaran agama itu amat luas, maka individu perlu menyisihkan sebagian waktu dan tenaganya untuk mempelajari ajaran agama secara rutin dengan memanfaatkan berbagai sumber dan media.

Peran konselor pada tahap ini adalah sebagai pendorong dan sekaligus pendamping bagi individu dalam mempelajari dan mengamalkan ajaran agama, dengan demikian diharapkan secara bertahap individu mampu membimbing dirinya sendiri 
c. Mendorong dan membantu individu memahami dan mengamalkan iman, Islam dan ikhsan.

1) Aktualisasi rukun iman dalam kehidupan sehari-hari:

a) Hanya beribadah kepada Allah dan tidak kepada yang lain.

b) Beribadah dengan niat yang tulus hanya semata-mata karena Allah.

c) Menyerahkan hasil usahanya hanya kepada Allah.

d) Yakin bahwa Allah memiliki makhluk gaib berupa malaikat.

e) Mematuhi apa yang diajarkan Allah dalam Al-Qur'an.

f) Mematuhi apa yang diajarkan oleh Rasulullah.

g) Ikhlas menerima ketentuan Allah atas dirinya.

h) Yakin bahwa akan datang hari pembalasan, dan setiap manusia akan mendapatkan balasan dari apa yang dilakukannya selama hidup di dunia.

2) Aktualisasi rukun Islam dalam kehidupan sehari-hari;

a) Meninggalkan segala macam bentuk syirik.

b) Mengamalkan syari'at yang dibawa oleh Rasulullah saw.

c) Mendirikan shalat wajib dan sunnah secara benar

d) Ikhlas mengeluarkan sebagian hartanya untuk infaq, zakat, dan atau shadaqah.

e) Melaksanakan puasa wajib dan sunnah secara benar.

f) Menunaikan ibadah haji sesuai ajaran agama.

3) Aktualisasi ikhsan dalam kehidupan sehari-hari; 
a) Selalu menjaga lidah (selalu berbicara dengan baik, berbicara hanya yang bermanfaat, tidak berdusta, tidak mengadu domba, tidak ghibah)

b) Menjauhkan diri dari penyakit hati (tidak buruk sangka, hasud, iri hati, sombong, dendam, riya', mudah marah- marah)

c) Menjauhkan diri dari perbuatan yang membahayakan (tidak merokok, mubadzirkan harta, makan dan minum secara berlebihan)

d) Selalu menjaga kesehatan (jika sakit ia berobat, tidak berobat dengan sesuatu yang diharamkan Allah, menjaga diri dari perbuatan yang membahayakan tubuh dan mental)

e) Sikap terhadap sesama muslim: jika bertemu teman memberi salam dan berjabat tangan, bermuka manis, menghormati,dan berkasih sayang.

f) Sikap terhadap orangtua (ayah dan ibu): senantiasa berbuat baik, tidak mendurhakai, bertutur kata lembut, mendo'akan orangtua, dan menjaga hubungan baik dengan sahabat orangtua.

d. Nuansa Konseling

Peran utama konselor dalam konseling dengan pendekatan ini adalah sebagai pengingat yaitu sebagai orang yang mengingatkan individu yang dibimbing dengan cara Allah. Dikatakan mengingatkan sebab: 1) pada dasarnya individu telah memiliki iman, jika iman tidak tumbuh diduga lupa merawatnya, lupa memberi pupuknya atau diserang penyakit. Akibatnya iman tidak tumbuh dan berfungsi dengan baik, 2) Allah telah mengutus Rasul-Nya dengan membawa kitab suci sebagai 
pedoman hidup, jika ada individu yang mengalami kebingungan atau salah jalan di duga mereka belum memahami petunjuk itu. Oleh karena itu bagi Konselor berkewajiban mengingatkannya.

Esensi konseling dengan pendekatan ini adalah upaya membantu individu belajar mengembangkana fitrah dan atau kembali pada fitrah. Cara-cara yang diajarkan oleh Allah yaitu 1) Dengan cara yang terbaik, dengan rujukan yang paling benar atau bebas dari kesalahan, dan mendatangkan manfaat atau kebaikan yang paling besar. 2) Gemar ucapan yang menyentuh hati dan mengantar kepada kebaikan, agar ucapan itu bisa menyentuh hati, maka perlu keteladanan dari yang menyampaikannya. 3) Jika perlu dilakukan diskusi maka diskusi itu dilakukan dengan cara-cara yang baik yaitu dengan argumen yang bisa diterima.

e. Evaluasi

Untuk mengevaluasi hasil konseling bisa dilakukan dengan mengamati perubahan aktualisasi iman, Islam, dan ikhsan individu dalam kehidupan sehari-hari. Namun demikian diakui, bahwa untuk melihat dan menilai keimanan seseorang adalah tidak mudah karena (a) ada individu tertentu yang lebih suka merahasiakan kebaikan yang dilakukannya demi menjaga kesucian niyat, (b) ada pula yang lahhiriyahnya kepada Allah, tetapi niyat yang sebenarnya tidak mudah diketahui dengan pasti, (c) pada dasarnya hanyalah Allah swt, yang paling mengetahui kualitas keimanan seseorang yang sebenarnya. 
5. Mencegah Kehamilan di Luar Nikah

Munculnya pemberitaan di berbagai media tentang adanya siswa Sekolah Dasar, siswa SMP, siswa SMA diperkosa dan bahkan terjadi kehamilan di luar nikah. Data lain yang dimuat KapanLagi.com menunjukkan bahwa menurut hasil survei yang dilakukan salah satu lembaga, $63 \%$ remaja Indonesia usia sekolah SMP dan SMA sudah melakukan hubungan seksual di luar nikah dan $21 \%$ di antaranya sudah melakukan aborsi.

Hasil survei terakhir suatu lembaga survei yang dilakukan di 33 provinsi tahun 2008, sebanyak $63 \%$ remaja mengaku sudah melakukan hubungan seks sebelum menikah. Kata Direktur Remaja dan Perlindungan Hak-Hak Reproduksi Badan Koordinasi Keluarga Berencana Nasional Pusat (BKKBN) M. Masri Muadz, saat peluncuran SMS Konsultasi Kesehatan Reproduksi Remaja di Serang. Jum'at 19-12-2008.

Ia juga mengatakan persentase remaja yang melakukan hubungan seksual pra nikah teraebut mengalami peningkatan jika dibandingkan dengan tahun-tahun sebelumnya.

Berdasarkan data penelitian pada tahun 2005-2006 di kota-kota besar mulai Jabotabek, Medan, Jakarta, Bandung, Surabaya dan Makasar, masih sekitar 47,54 \% remaja mengaku melakukan hubungan seks di luar nikah.

Sebab-sebab terjadinya kehamilan di luar nikah antara lain: anak kurang memahami dan mengamalkan ajaran agama dengan baik dan benar, adanya pergaulan bebas di kalangan remaja usia sekolah, kecenderungan remaja meniru gaya kehidupan yang dilihat di internet dan kurangnya pengawasan orang tua. 
Berpijak data di atas maka diketahui bahwa perilaku seks bebas remaja saat ini sudah cukup parah. Peranan agama dan keluarga sangat penting mengantisipasi perilaku remaja tersebut." Solusi yang dapat dilakukan di sekolah adalah melalui program bimbingan dan konseling dengan model Bimbingan dan Konseling Islami.

\section{Penutup}

Dari uraiann di atas maka dapat disimpulkan bahwa untuk mencegah terjadinya kehamilan remaja diluar nikah maka dapat dilakukan: (1) pengawasan orangtua, (2) peningkatan pemahaman ajaran agama, dan (3) melalui model bimbingan dan konseling Islami

\section{Daftar Pustaka}

Aliah B. Purwakania Hasan. 2006. Psikologi Perkembangan Islami. Jakarta: PT Raja Grafindo Persada.

Anwar Sutoyo. 2007. Bimbingan dan Konseling Islami. Semarang: Cipta Prima Nusantara.

Hanna Djumhana dkk. 2003. Islam Untuk Disiplin Ilmu Psikologi. Jakarta: Departemen Agama RI Disrektorat Jenderal Kelembagaan Agama Islam.

M Hamdani Bakran Adz-Dzaky. 2002. Konseling \& Psikoterapi Islam, Jogjakarta: Fajar Pustaka Baru.

Tantri Yusepa. 2010. Pengaruh Perhatian orang tua dan Frekuensi Mengikuti Kegiatan Agama Terhadap Kecenderungan melakukan Hubungan Seks saat berpacaran. Jakarta: Departemen Agama RI Disrektorat Jenderal Kelembagaan Agama Islam. 
